\title{
Satisfying the Housing Needs of Disabled Citizens in North-Eastern Poland
}

\author{
Marcelina Zapotoczna, Ph D \\ University of Warmia and Mazury in Olsztyn, Department of Finance and Banking
}

\begin{abstract}
:
Since disabled people have lower income and their geographical mobility is lower, they often tolerate inappropriate housing conditions, i.e. conditions that do not suit the type and degree of their disability. This article presents the results of interviews conducted among people affected by various degrees of disability. The main aim of the study was to determine the housing needs in regard to quality and to the extent to which the needs are satisfied by people living in the north-east of Poland. The first stage of the study involved identification of the factors that determine the quality of housing that satisfies the basic needs and barriers which prevent performing everyday activities. Subsequently, a multidimensional analysis was conducted to assess the extent to which the housing needs are satisfied in groups identified by the degree of disability. The synthetic measures and distance-related indexes suggested the existence of large diversity in the level of satisfaction of housing needs in the groups of disabled people under study.
\end{abstract}

Keywords: housing needs, disabled people, multidimensional analysis

\section{Introduction}

Measures aimed at providing equal opportunities, including improvement of housing conditions, are an important aspect of social life in the rapidly changing socioeconomic environment. The housing standards of disabled people are not comparable to those of the rest of the population. A home, which is the central point of their existence (Disabled..., 2012), cannot be an obstacle on the road to a life of dignity. The everyday life of a disabled person is difficult. Therefore, in the author's opinion, it is extremely important to identify the housing needs of this social group. In such cases, a subjective assessment of the extent to which one's housing needs are satisfied is very important. Hence, a particular weight must be assigned to examining the current housing conditions of the disabled and identifying the expectations and needs in this regard, both conscious and otherwise, and indicating the barriers that people with disability of various kinds must overcome at their flats and their surroundings. It seems to be of fundamental importance to evaluate the willingness of the disabled to remove the barriers, which is a key factor in regard to improvement of their housing conditions. It is both important and topical to act with a view to improving the housing conditions due to - inter alia - an increasing number of disabled people. The number of disabled people is increasing - according to the $\mathrm{WHO}^{1}$ - due to the population ageing and increasing incidence of chronic diseases, such as diabetes, cardiovascular diseases, cancers and mental disorders. Therefore, it is of key importance how disabled people are perceived by local communities. It is difficult to define disability because it is difficult to define a border between a person who is not fully able and one who is fully able, as well as to determine the burden of disability. However, it must be stressed that not every dysfunction of the body constitutes a disability. Limitations suffered by disabled people vary and depend on the type and degree of damage to various organs of the body or

\footnotetext{
${ }^{1}$ It is important to point out, at this point, that the aforementioned Agreement establishes the following: "Minors who have left FARC-EP camps since the beginning of the peace talks, as well as those who leave until the end of it, will be object of special attention and protection measures that will be discussed in the National Council of Reintegration in the framework of the Commission of Follow-up, Impulse and Verification of the Implementation of the Final Agreement (CSIVI)... To these minors will be granted all the rights, benefits and privileges established for the victims of the conflict, as well as those derived from their process of reincorporation in the terms contemplated in this Final Agreement ... "(High Commissioner for Peace, 2016, p. .74). This means that the boys and girls who belonged to the guerrilla group and leave their ranks, will no longer have the status of ex-combatants, but will be considered victims of the conflict. This point has a fundamental importance for the process of reconstruction of the social fabric, because it will enable the reparation of these children who were born in the middle of, or were dragged into, that armed conflict, and that is why they have precisely the connotation victims
} 
simultaneous damage to several organs. Permanent or temporary limitations or even an inability to perform activities cover all the aspects of life, which contributes to the specificity of satisfying many needs, including housing needs. A home where one satisfies one's needs, not only the basic needs, but also higher needs, becomes an asylum (taszek, 2004). When the higher needs are satisfied, a person can develop intellectually, emotionally and socially (Gawron, 2012). However, it must be emphasised that the housing needs based on subjective determination of one's housing requirements and an individual understanding of the standard depend on the financial capabilities of households. Hence, part of society expects the state to aid in satisfying their housing needs and it is the duty of the authorities to eliminate unjustified differences in accessibility of homes and decent quality of life.

A diagnosis of the housing conditions of disabled people helps to determine the actual extent to which the housing needs specific to this group of people are satisfied, while the existing gap in the knowledge on the issue indicates the need for further studies. This article presents the results of interviews conducted among people affected by disability to various degrees. The main aim of the study was to determine the housing needs in regard to quality and the extent to which the needs are satisfied by people living in north-eastern Poland.

\section{Specific housing needs of disabled people}

The issue of satisfying one's housing needs is common and is faced by everyone and it remains valid throughout everyone's life. The need to have a home is - along with the need for food and clothing - the most important of human needs. Housing market researchers have stressed that the level of satisfying the housing needs affects all aspects of human life because the proper housing conditions enable one to fulfil one's life goals, both on a personal and a professional level (Foryś, 2011, Gazińska 2006, Szelagowska 2011, 2012, Zapotoczna 2014). In the quantitative dimension, housing needs determine the number of houses necessary for independent residence. The qualitative dimension determines the physical characteristics, such as the size of a flat, but mainly its spatial and functional layout and the quality standard. Ensuring the optimum conditions for satisfying one's housing needs should enable disabled people to satisfy all their needs, regardless of their psychophysical condition. The following characteristics gain particular importance in the case of disabled people: freedom, comfort, independent use, self-fulfilment, security and social integration. All of these are components of the quality of life. Subjective needs which arise from individual preferences result in different expectations of each disabled person. Moreover, it is extremely important to be able to make qualitative changes in order to adapt a flat to the current needs of its user. Each flat should be designed so that it can be adapted to the disability of its resident. Adaptation of the functional layout of a flat should depend on the type and degree of disability. Elements of special adaptation of houses and flats to the needs of the disabled include ${ }^{1}$ :

1)in regard to accessibility of external area;

a)providing sufficient space for moving in wheelchairs,

b)adjusting the height of kerbs and steps,

c) proper signs, position and size of parking places, with anti-slippery surface and without high kerbs,

2)in regard to accessibility of buildings:

a)adapting building entrances by installing doors of the right parameters which can be accessed from the ground level with the use of ramps and steps, lifts or elevators; the surface of these devices should be made of anti-slippery material;

b)ensuring sufficient space before and behind a ramp to enable free manoeuvring of a wheelchair and opening the door by a disabled person,

\footnotetext{
1 See for example, Dale Jamieson, "When Utilitarians Should Be Virtue Theorists," Chapter 17 in Stephen M. Gardiner, Simon Caney, Dale Jamieson and Henry Shue (eds.), Climate Ethics: Essential Readings (Oxford: Oxford University Press, 2010) and Climate Matters: Ethics in a Warming World (New York: W. W. Norton \& Company, 2012). For a critical discussion, see Walter Sinnott-Armstrong, "It's Not My Fault: Global Warming and Individual Moral Obligations," Chapter 18 in Stephen M. Gardiner, Simon Caney, Dale Jamieson and Henry Shue (eds.), Climate Ethics: Essential Readings (Oxford: Oxford University Press, 2010); and Jessica Nihlén Fahlquist, "Moral Responsibility for Environmental Problems_-Individual or Institutional?," Journal of Agricultural Environmental Ethics 22 (2009), 109124.
} 
c) touch signs on steps and contrast signs along ramps and on landings,

d)adaptation of stairs by ensuring appropriate height and width of steps and the number of steps,

e) fitting out lifts with appropriate control panels with sound and light signalling of a lift stop,

f) fitting out doors with ergonomic handles and hand rails,

g)installing entry-phones in the roofed area at an appropriate height and fitting out with traditional keyboard (preferably numerical),

h)installing bells and light switches at an appropriate height,

i) appropriate position and size of parking spaces with suitable access road,

3) in regard to accessibility of a flat:

a)ensuring the appropriate size and shape of rooms in a flat, with sufficient passages and space for manoeuvring as well as the floors enabling easy movement,

b)adaptation of doors,

c) fitting windows at an appropriate height, with appropriate opening handles;

d)equalising the floor level in rooms,

e)fitting out doors with ergonomic handles or sliding or folding doors,

f) installing switches and sockets at the appropriate height, of the appropriate type and colour,

g)designing the kitchen in accordance with the rules of ergonomics, with the minimum manoeuvring area, and fitting it out with a set of cupboards of the appropriate height and width of the board and kitchen appliances with appropriate access to them,

h)appropriate position of the bathroom and equipping it properly, with the minimum manoeuvring area, while observing the rules of ergonomics, functionality and safety, with anti-slippery floor;

i) fitting out the bathroom with devices that enable their safe use and installing handles, lift, seat, etc.;

j) placing the bathroom close to the bedroom;

k) applying proper lighting as well as sound or light signalling devices;

I) fitting out with appropriate smelling elements, furniture and other equipment, deployed properly;

m) fitting out with various alarm systems (e.g. wireless, cable, photo cells).

\section{Methodology}

This study was taken up because of the need for examining the extent to which the housing needs of people with various level of disability are satisfied and for identifying the barriers with which they have to contend in their flats and in the surroundings. The main aim of the study was to determine the housing needs in regard to quality and the extent to which the needs are satisfied by people living in north-eastern Poland (Warmińsko-Mazurskie Voivodship). A diagnosis of the housing conditions of disabled people, which provided the basis for determination of the actual extent to which the housing needs specific to this group of people are satisfied, was an important study area. Since at least two definitions of disability are applied in Poland, the study was conducted on people with valid disability certificates, issued by disability evaluation boards. Such certificates provide the grounds for applying for and obtaining special aid and privileges.

A number of research methods were used in the study. The desk research technique was applied in order to gather the necessary information. The analysis of secondary data was a starting point for field research. The first stage of the field research involved in-depth interviews with 10 representatives of entities conducting activities for disabled people. In this research, we used objectified cases to specify and develop detailed issues related to housing needs and the improvement 
opportunities regarding housing conditions. The second stage involved direct interviews with 148 disabled people. The group under study was divided according to the degree of disability, i.e. group 1 - 23 people with mild disability, group 2 80 people with moderate disability and group $3-45$ people with severe disability.

The data were used to identify the factors that determine the quality of housing that satisfies the basic needs and barriers which prevent performing everyday activities. The last stage of the study involved comparing the extent to which the housing needs are satisfied and the degree of satisfaction of the interviewees with their housing conditions and to their willingness to change the place of residence.

The synthetic method was used to evaluate the housing needs. Owing to the WAP multidimensional comparative analysis, a sizeable set of variables was replaced with one - syntheticvariable. A typical measure, proposed by Hellwig (1969), was used in the article; it is usually applied in empirical studies and it belongs to a group of standard-based methods. The groups of disabled people under study made up a 3-item set $\Omega$ of so-called taxonomic operational units described with 15 diagnostic variables, which were based on data obtained in the survey. The taxonomic synthetic index of the level of satisfying the housing needs was calculated from the formula:

$$
D_{\mathrm{i}}=1-\frac{c_{\mathrm{i} 0}}{c_{0}} \text {, }
$$

where $\quad c_{0}=\overline{c_{0}}+2 \mathrm{~s}_{0}$

with:

$\overline{\mathrm{c}_{0}}$ - mean value of the calculated distances $\mathrm{c}_{\mathrm{i} 0}$

So - standard deviation of the distance cio.

Destimulants were replaced with stimulants, which is why the values of the index lie within the range of $[0,1]$. The closer the value of the measure to 0 , the lower the level of satisfying the needs in the group.

Subsequently, the distance formula proposed by Roeske - Słomka (1998) was used to calculate the distance of satisfying housing needs in the 3 groups of disabled people under study. The distance indices were calculated from the formula:

$d_{i r}=\left[\left(\frac{x_{i j}}{x_{\min j}}-1\right):\left(\frac{x_{\max / \min j}}{x_{\min j}}-1\right)\right] \cdot e_{i r} \cdot 100$

where:

$x_{i, j}$ - so-called empirical level of satisfying the i-th need in a given population,

$x_{\min j}$ - the minimum level of satisfying the $\mathrm{i}$-th need in a given population,

$x_{\max / \min j}$ - the optimum level of satisfying the $\mathrm{i}$-th need, with: the lowest value of the $\mathrm{i}$-th variable in a given group of disabled people, - for variables which are stimulants or the highest value of the i-th value in a given group, - for variables which are destimulants,

$e_{i r}$ - the index of homogeneity of distribution of satisfying the i-th need in a given population,

The values of the distance index lie within the range of $d_{i j} \in[0,1]$. The distance index $d_{i j}$ takes the value of 0 for the $j$-th group, in which the given feature $x_{i}$ was achieved to the minimum extent. It does not mean that $x_{i j}$ was equal to 0 , but that the distance that the given group of disabled people has to cover to reach the maximum level (for the objects under study rather than for hypothetical standards) is $100 \%$. On the other hand, the value of 1 is taken by an index which corresponds 
to a group of disabled people with the highest value of feature $x_{i}$ assuming that $e_{i}=1$, i.e. the distribution of feature $x_{i}$ is completely homogeneous. It must be emphasised that $d_{i j}=1(100 \%)$ will mean that the $j$-th group can be taken as the standard with respect to a given feature $\mathrm{x}_{i}$ in regard to satisfying the housing needs.

\subsection{Measure of housing needs of disabled people}

The basis for evaluation of the housing needs was made up of variables whose construction was based on data obtained in a direct interviews with disabled people, their families or carers living in the same household. An analysis of the housing conditions of disabled people living in the area under study helped us to identify the technical and spatial parameters of evaluation of the residential space and architectural barriers present in the surroundings of a house and in the residential space, which affect the meeting of housing needs and, in consequence, the quality of life. The diagnostic data accumulated in the study were categorised based on the coefficients of variation (the coefficient of variation for the $i$-th variable was higher than 10\%), coefficients of correlation (strongly correlated variables were discarded) and standard deviation. Subsequently, the selected set of variables was arranged by standardisation in order to make it comparable. Ultimately, a set of 15 variables was obtained which describe different areas of evaluation of the extent to which housing needs are satisfied.

- the building entrance and surroundings:

$\mathrm{x}_{1} \%$ of buildings at whose entrances there are architectural barriers, e.g. too high kerbs, damaged or no pavements.

$\mathrm{x}_{2} \%$ of buildings at whose entrances there are no ramps or driveways.

$x_{3} \%$ of buildings near which there are no parking spaces for the disabled.

$\mathrm{x}_{4} \%$ of buildings near which there are improper surfaces (e.g. not hardened, uneven, slippery, such that make movement difficult).

- space inside a multi-family building:

$\mathrm{x}_{5} \%$ of flats which are not easily accessible to disabled people as the passages within them are not adapted to their disability (small landings, no lift or platform);

- residential space:

$\mathrm{x}_{6} \%$ of flats with thresholds between rooms, which hinder moving around the flat.

$\mathrm{x}_{7} \%$ of flats in which the type of floor was not adapted to the needs of disabled people(e.g. no anti-slippery floor).

$\mathrm{x}_{8} \%$ of flats in which doors are not adapted to the need of disabled people who live in them.

$x_{9} \%$ of flats in which the type and position of door handles were not adapted to the disability of the people who live there.

$\mathrm{x}_{10} \%$ of flats in which the type and method of door opening was not adapted to the disability of the people who live there.

$x_{11} \%$ of flats in which the type and position of switches and sockets was not adapted to the disability of the people who live there.

$\mathrm{x}_{12} \%$ of flats in which the area of rooms in the flat (bathroom, kitchen, bedroom, study) was not adapted to the disability of the people who live there.

$\mathrm{x}_{13} \%$ of flats which were not fitted out with appropriate devices enabling one to use a bathroom safely and freely (e.g. type and positioning the bathroom facilities, handrails).

$\mathrm{x}_{14} \%$ of flats in which furniture (cupboards, table, household appliances) was not positioned functionally and not adapted to the disability of the people who lived in them.

$x_{15} \%$ of flats with a wrong position of the bedroom relative to the bathroom.

\section{A multidimensional analysis of satisfying housing needs}

\subsection{The level of satisfying the housing needs}

Considering the fact that the population of disabled people is not homogeneous and requires a separate approach to each type of disability (various types of disability are associated with various issues and barriers), the degree to which housing needs are satisfied was evaluated for the three groups identified by the degree of disability, i.e. mild, moderate and severe. Subsequently, the groups under study were arranged according to a synthetic measure of satisfying the housing needs $d_{i}$ in order to compare the extent to which the housing needs are satisfied. 
Owing to the synthetic approach to measure $d_{i}$, which cannot be determined directly, it could be regarded as a measure of satisfying the housing needs of disabled people who live in the north-east of Poland. The measure was constructed while taking into account the main areas of evaluation of housing conditions made by disabled people. A detailed construction of the index was presented in the study methodology. The values of measure $d_{i}$ calculated for various groups are shown in Table 1.

Table 1. Values of the synthetic measure

\begin{tabular}{|c|c|c|c|c|c|c|c|c|c|c|c|c|c|c|c|c|c|}
\hline $\begin{array}{l}\text { Degree of } \\
\text { disability/Gro } \\
\text { up }\end{array}$ & $x_{1}$ & $x_{2}$ & $x_{3}$ & $\mathrm{X}_{4}$ & $x_{5}$ & $x_{6}$ & $x_{7}$ & $\mathrm{x}_{8}$ & $\mathrm{X}_{9}$ & $x_{10}$ & $x_{11}$ & $\mathrm{X}_{12}$ & $x_{13}$ & $x_{14}$ & $\mathrm{x}_{15}$ & $\mathrm{~d}_{\mathrm{i}}$ & $\begin{array}{l}\text { Ran } \\
\mathrm{k}\end{array}$ \\
\hline $\begin{array}{l}\text { People with } \\
\text { mild } \\
\text { disability }\end{array}$ & $\begin{array}{l}\text { ᄋे } \\
\text { ○ें }\end{array}$ & $\begin{array}{l}\text { ळें } \\
\infty \\
\text { ச }\end{array}$ & $\begin{array}{l}\text { ळे } \\
\text { సે }\end{array}$ & 离 & $\begin{array}{l}\text { ठें } \\
\text { iें }\end{array}$ & $\begin{array}{l}\text { oे } \\
\text { o } \\
\text { ले }\end{array}$ & 蒿 & $\begin{array}{l}\stackrel{\circ}{O} \\
\stackrel{9}{g}\end{array}$ & $\begin{array}{l}\stackrel{\circ}{0} \\
\stackrel{\text { mे }}{\stackrel{5}{\circ}}\end{array}$ & $\begin{array}{l}\stackrel{0}{0} \\
\text { jా }\end{array}$ & $\begin{array}{l}\stackrel{\circ}{\circ} \\
\text { م) }\end{array}$ & 产 & $\begin{array}{l}\stackrel{0}{\circ} \\
\stackrel{0}{+\infty} \\
\stackrel{y}{y}\end{array}$ &  &  & 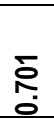 & 1 \\
\hline $\begin{array}{l}\text { People with } \\
\text { moderate } \\
\text { disability }\end{array}$ & 总 & 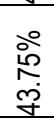 & $\begin{array}{l}\text { Oे } \\
\text { م⿱ } \\
\text { N }\end{array}$ & $\begin{array}{l}\stackrel{0}{\circ} \\
\stackrel{0}{0} \\
\stackrel{N}{N}\end{array}$ &  & 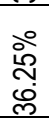 & $\begin{array}{l}\stackrel{0}{\circ} \\
\stackrel{1}{m} \\
\text { m }\end{array}$ & 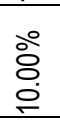 & 今̊ํํ & $\begin{array}{l}\text { 总 } \\
\text { م. }\end{array}$ & 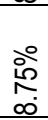 & $\begin{array}{l}\text { ᄋे } \\
\text { ᄋें }\end{array}$ & $\stackrel{\stackrel{\circ}{\circ}}{\stackrel{0}{6}}$ & 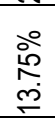 & 各 & $\begin{array}{l}\text { 员 } \\
\text { مै }\end{array}$ & 2 \\
\hline $\begin{array}{l}\text { People with } \\
\text { severe } \\
\text { disability }\end{array}$ & $\begin{array}{l}\stackrel{\circ}{8} \\
\stackrel{8}{+}\end{array}$ & 苗 & 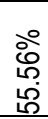 & $\begin{array}{l}\stackrel{\circ}{8} \\
\dot{y} \\
\end{array}$ & $\begin{array}{l}\text { ○े } \\
\text { ọ } \\
\infty\end{array}$ & $\begin{array}{l}\stackrel{\circ}{8} \\
\text { \& }\end{array}$ & $\underset{\frac{0}{5}}{\stackrel{\circ}{E}}$ & $\begin{array}{l}\stackrel{\circ}{+} \\
\stackrel{+}{+}\end{array}$ & $\stackrel{\circ}{\frac{\circ}{E}}$ & 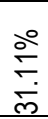 & \begin{tabular}{l} 
o̊ \\
స \\
\multirow{2}{*}{}
\end{tabular} & $\begin{array}{l}\text { oे } \\
\infty \\
\text { ò } \\
\text { iे }\end{array}$ & $\begin{array}{l}\text { స̃ } \\
\text { đิ }\end{array}$ & 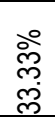 & $\stackrel{\circ}{\stackrel{\circ}{\risingdotseq}}$ & స్ু & 3 \\
\hline
\end{tabular}

Source: the author's calculations

The synthetic index of satisfying housing needs was the highest in the group with mild disability $(0.701)$ and the lowest - in the group with severe disability $(0.221)$. It can be seen from the values of the index that the phenomenon is highly diverse. A small value of the synthetic measure (0.221) for people with mild disability indicates that their housing needs are satisfied to a small extent.

From the perspective of the variables taken for the study, the number of people with a good opinion on how their housing conditions are adapted to their disability was the greatest in the group with mild disability and the smallest - in the group with severe disability. The value of 9 out of 15 variables of housing conditions assessment $\left(\mathrm{x}_{1}, \mathrm{x}_{3}, \mathrm{x}_{4}, \mathrm{x}_{5}, \mathrm{x}_{6}, \mathrm{x}_{7}, \mathrm{x}_{11}, \mathrm{x}_{12}, \mathrm{x}_{13}\right)$ was the smallest in the group of people with mild disability. This means that the percentage of people in this group in whose opinion their housing conditions were adapted quite well in the areas described by these variables was the highest. In consequence, in their opinion their housing needs were satisfied to a considerable extent. On the other hand, the values of 14 out of 15 variables taken for an assessment of the extent to which housing needs are satisfied were the highest in the group with severe disability. This means that the percentage of people in this group with a low opinion on the adaptation of the surroundings of the buildings and of the flats to their disability was the highest in nearly all of the areas (except $x_{9}$ ).

\subsection{Distance of satisfying the housing needs}

A multidimensional comparative analysis of the distance of satisfying the housing needs was conducted in order to compare the extent to which housing needs are satisfied in groups of people with different degrees of disability. The values of variables described in the section on the measures of housing needs of disabled people were taken characteristics of different areas of satisfying the needs. The distance formula is presented in detail in the methodology section. The distance indices of satisfying the housing needs in the groups of disabled people under study are shown in Table 2.

Table 2. The distance indices of satisfying the housing needs

\begin{tabular}{|l|l|l|l|l|}
\hline \multirow{2}{*}{$\begin{array}{l}\text { Diagnostic } \\
\text { variables }\end{array}$} & \multicolumn{2}{|l|}{ Distance index of satisfying need $\mathrm{d}_{\mathrm{i}}$} & \multirow{2}{*}{$\boldsymbol{d}_{i}$} \\
\cline { 2 - 4 } & People with mild disability & People with moderate disability & People with severe disability & \\
\hline $\mathrm{x}_{1}$ & $27.36 \%$ & $32.77 \%$ & $19.24 \%$ & $\mathbf{2 6 . 4 6 \%}$ \\
\hline $\mathrm{x}_{2}$ & $55.65 \%$ & $50.91 \%$ & $42.14 \%$ & $\mathbf{4 9 . 5 7 \%}$ \\
\hline $\mathrm{x}_{3}$ & $90.29 \%$ & $48.32 \%$ & $28.27 \%$ & $\mathbf{5 5 . 6 2} \%$ \\
\hline $\mathrm{x}_{4}$ & $21.77 \%$ & $28.79 \%$ & $14.08 \%$ & $\mathbf{2 1 . 5 5 \%}$ \\
\hline $\mathrm{x}_{5}$ & $22.88 \%$ & $40.57 \%$ & $40.57 \%$ & $\mathbf{3 4 . 6 8 \%}$ \\
\hline $\mathrm{x}_{6}$ & $38.55 \%$ & $40.18 \%$ & $31.44 \%$ & $\mathbf{3 6 . 7 3 \%}$ \\
\hline
\end{tabular}




\begin{tabular}{|l|l|l|l|l|}
\hline $\mathrm{X}_{7}$ & $35.00 \%$ & $38.81 \%$ & $23.11 \%$ & $\mathbf{3 2 . 3 1 \%}$ \\
\hline $\mathrm{X}_{8}$ & $94.58 \%$ & $72.51 \%$ & $38.69 \%$ & $\mathbf{6 8 . 5 9 \%}$ \\
\hline $\mathrm{X}_{9}$ & $95.12 \%$ & $45.58 \%$ & $43.00 \%$ & $\mathbf{6 1 . 2 3} \%$ \\
\hline $\mathrm{X}_{10}$ & $90.01 \%$ & $60.38 \%$ & $25.32 \%$ & $\mathbf{5 8 . 5 7 \%}$ \\
\hline $\mathrm{X}_{11}$ & $95.24 \%$ & $95.83 \%$ & $46.87 \%$ & $\mathbf{7 9 . 3 1 \%}$ \\
\hline $\mathrm{X}_{12}$ & $46.95 \%$ & $43.20 \%$ & $32.51 \%$ & $\mathbf{4 0 . 8 9 \%}$ \\
\hline $\mathrm{X}_{13}$ & $44.50 \%$ & $62.70 \%$ & $43.81 \%$ & $\mathbf{5 0 . 3 4 \%}$ \\
\hline $\mathrm{X}_{14}$ & $66.87 \%$ & $42.30 \%$ & $27.58 \%$ & $\mathbf{4 5 . 5 8 \%}$ \\
\hline $\mathrm{X}_{15}$ & $82.74 \%$ & $28.54 \%$ & $\mathbf{3 1 9 . 9 5 \%}$ & $\mathbf{4 3 . 7 4 \%}$ \\
\hline $\boldsymbol{d}_{i}$ & $\mathbf{5 6 . 2 5 \%}$ & $\mathbf{4 9 . 6 4 \%}$ & $\mathbf{3 1 . 5 3 \%}$ & $\mathrm{x}$ \\
\hline
\end{tabular}

Source: the author's calculations

These calculations helped to determine the distance to the maximum level, determined for all the groups of disabled people that must be covered by the given group of the disabled with respect to the feature taken for the analysis.

The general distance indices (the last line in Table 2) show that the housing needs are satisfied to a rather small extent in all the groups of the disabled. The best situation was found in the group with mild disability - the distance from the maximum level was $43 \%$ and the worst - in the group with severe disability. The distance in this group was ca. $50 \%$.

From the perspective of the variables taken for analysis, it was found that:

1) in the group of people with mild disability:

i in terms of satisfying the housing needs defined by the variables taken for analysis, the situation was the best in adaptation of the flats to the disability of people who live in them in regard to the position and type of switches and sockets, position of door handles and the size of doors. The distance from the maximum level was approx. $5 \%$. A slightly worse situation was noted in regard to the method of opening the doors and their type (hinged doors opened to the inside, folded doors, sliding doors). The distance in this regard was $10 \%$.

a The situation in this group of disabled people was the worst in terms of adaptation of the building surroundings in regard to proper access roads and pedestrian passages. The distance from the maximum level was approx. $80 \%$ The situation in regard to adaptation of building entrances was similar. A considerable percentage of buildings with architectural barriers at the entrance was found. The distance in this regard was $73 \%$.

2 ) in the group of people with moderate disability:

- The distance index of satisfying the housing needs was the best in adaptation of the flats in regard to the type and position of switches and sockets. The distance in this regard was nearly $4 \%$. The situation was slightly worse in regard to the number of parking spaces for disabled residents. The distance from the maximum level was just under $10 \%$.

a As in the group of people with mild disability, the situation was the worst in adaptation of building entrances. There was a considerable percentage of buildings with architectural barriers in this group. Also, disabled people found it difficult to move around due to lack of adaptation of the building surroundings. The distance in this case was a little over $70 \%$, it was lower by 3 pp compared to the group of people with mild disability.

3) in the group of people with severe disability:

- The situation was the best in adaptation of the flats in regard to the type and position of switches and sockets and the position of door handles. Moreover, the situation was relatively good in regard to fitting out the bathrooms with equipment facilitating their free and safe use (e.g. proper position of bathroom fixtures, installing handrails). The opinion of the respondents was similar in regard to fitting out the buildings with platforms, ramps or other devices facilitating movements of disabled people. The distance from the maximum level in these areas of assessment was just under $60 \%$.

- Also in this group, the situation was the worst in regard to adaptation of the building surroundings to the needs of disabled residents (the distance from the highest level was nearly $86 \%$ ). Moreover, a large distance (approx. $80 \%$, i.e. larger by 7 p.p. compared to the group of people with mild disability and by 10 p.p. compared to the group of people with moderate disability) from the maximum level was found in adaptation of building entrances. 
Considering the variables describing the extent to which the housing needs of the disabled are satisfied in north-eastern Poland (Warmińsko-Mazurskie Voivodship), it has been shown that:

- The distance index of satisfying the housing needs in terms of the variables taken for analysis in all the groups of the disabled was the best in adaptation of the flats in regard to the type and position of switches and sockets. The distance in this regard was approx. $21 \%$.

- The situation was the worst in terms of adaptation of building entrances by removing architectural barriers. The distance from the maximum level in this case was slightly over $73 \%$ The situation was also adverse for the disabled in terms of adaptation of the building surroundings with a view to making it easier for the disabled to move around. The distance from the maximum level was just over $78 \%$.

\subsection{Level of satisfaction with housing conditions}

The level of satisfaction with housing conditions was evaluated in the last stage. The ranking of the levels of satisfaction with the housing conditions by the degree of disability is shown in Table 3.

Table 3 Summary of the levels of satisfaction with the housing conditions

\begin{tabular}{|l|l|l|l|l|l|}
\hline \multirow{2}{*}{ Degree of disability } & \multicolumn{4}{|l|}{ Evaluation of housing conditions } \\
\cline { 2 - 6 } & Absolutely not & Rather not & Hard to say & Rather yes & Absolutely yes \\
\hline mild & $13.04 \%$ & $8.70 \%$ & $4.35 \%^{*}$ & $52.17 \%^{* *}$ & $21.74 \%$ \\
\hline moderate & $8.75 \%$ & $12.50 \%$ & $7.50 \%^{*}$ & $43.75 \%^{* *}$ & $27.50 \%$ \\
\hline severe & $13.33 \%$ & $13.33 \%$ & $6.67 \%^{*}$ & $42.22 \%^{* *}$ & $24.44 \%$ \\
\hline
\end{tabular}

${ }^{*}$ categories and population sizes of the lowest incidence

${ }^{* *}$ categories and population sizes of the highest incidence

\section{Source: the author's calculations}

The study results have shown that approx. $21 \%$ of the group of people with mild and moderate disability are rather satisfied or highly satisfied with their housing conditions. On the other hand, over $70 \%$ are rather or highly dissatisfied. Among the people with severe disability there was a slightly higher percentage of people rather or highly dissatisfied (approx. 27\%), whereas the percentage of rather or highly satisfied with their housing conditions was slightly under $70 \%$. Therefore, despite not having a very high level of satisfying housing needs, the majority of the disabled people were satisfied with their housing conditions. In each of the groups under study there was a considerable percentage (approx. $70 \%$ ) of people who were not interested in exchanging their flat for a smaller or larger one or in the purchase of a new one which would be better suited to their disability, even if they received a non-returnable subsidy. These people felt they needed to improve their housing conditions, but in their opinion the effectiveness of such actions depended on the financial aid received. The reasons for this state could include the fact that they are accustomed to their place of residence and their environment despite their low opinion of it and their financial situation, because social benefits were the main source of income for disabled people in each of the groups under study (approx. 90\% of the respondents)

\section{Summary}

This article presents an assessment of the extent to which the housing needs are satisfied and an assessment of satisfaction with their housing conditions based on a survey conducted among people with various degrees of disability. The study involved seeking determinants of satisfying the housing needs of disabled people; therefore, a particular weight was assigned to examination of the current housing conditions, focusing on the key areas of the qualitative assessment of the housing conditions of the people under study. The methods employed in the study helped to evaluate the extent to which the housing needs were satisfied. The synthetic measures calculated in the study suggested the existence of large diversity of the level of satisfying the housing needs. On the other hand, owing to the distance formula it was possible to compare the overall level of satisfying the housing needs in the groups of disabled people from the perspective of the variables taken for analysis. The distance indices $d_{i}$ showed that, in general, the level of satisfying the housing needs in all the groups under study was not high. A subjective assessment made by the respondents, arising from the individual preferences, resulted in different expectations in each of the groups under study. The expectations varied in regard to the size, standard and the functionality of the layout. 
The study results have identified the directions of actions aimed at improvement of the housing conditions of disabled people, in line with their expectations and needs. They have also provided scientific evidence for political projects and programmes which can improve the level of satisfying the housing needs of disabled people.

\section{Literature}

[1] Disabled Housing Needs Study - An Assessment of the Housing Needs of People with Physical Disabilities. Nottinghamshire and Derbyshire Strategic Housing. Local Authorities Local. Report for Amber Valley Borough Council. 19September 2012, 1011

[2] Foryś I. (2011), Społeczno - gospodarcze determinanty rozwoju rynku mieszkaniowego w Polsce. Ujęcie ilościowe. US, Rozprawy i studia T. (DCCCLXVII)793, 145-2011

[3] Gawron H. (2012), Potrzebymieszkanioweklientównalokalnymrynkunieruchomościmieszkaniowych i sposoby ich zaspokajania. Wyd. UE w Poznaniu, 42

[4] Gazińska M. (2006), Demograficzne uwarunkowania potrzeb mieszkaniowych, w: Prognoza popytu i Porażyna rynku mieszkaniowym w świetle zaspokojenia potrzeb mieszkaniowych projekt badawczy KBN nr 1H02B01327. US, Szczecin

[5] Hellwig Z. (1969), Zastosowanie metody taksonomicznej do typologicznego podziału krajów ze względu na poziom ich rozwoju oraz zasoby i strukturę wykwalifikowanych kadr. Przegląd Statystyczny z. 4, 307-327

[6] Kowalski K. Mieszkanie dostępne dla osób z dysfunkcjami wzroku; Biblioteka dla Osób Niepełnosprawnych, [Online]

[7] Kowalski K. Planowanie dostępności - prawo w praktyce; Biblioteka dla Osób Niepełnosprawnych, [Online]

[8] Łaszek J. (2004), Sektor nieruchomości mieszkaniowych w Polsce. Stan i perspektywy. SGH Monografie i Opracowania 525, Warszawa, 48-52; 297-306

[9] Nowak E., Budny J., Kowalski K. Mieszkanie dostępne dla osób z dysfunkcją narządu ruchu; Biblioteka dla Osób Niepełnosprawnych, [Online]

[10] Roeske - Słomka I. (1998), Dystanszaspokojeniapotrzebmieszkaniowychludnościwedługmakroreginów. Wiadomości Statystyczne, nr 4, $36-41$

[11] Rozporządzenie Ministra Infrastruktury w sprawie warunków technicznych, jakim powinny odpowiadać obiekty budowlane metra i ich usytuowanie. Dz.U. z 2011r. Nr 144, poz. 859 z późn. zm.

[12] Rozporządzenie Ministra Infrastruktury w sprawie warunków technicznych, jakim powinny odpowiadać budynki ich usytuowanie z dnia 12 kwietnia 2002r., Dz.U. z 2002r. Nr 75 poz. 690 z późn. zm.

[13] Szelagowska A. (2011), Finansowanie społecznego budownictwa mieszkaniowego, CeDeWu.pl Warszawa, 23-81

[14] Ustawa Prawo budowlane z dnia 7 lipca 1994r. Dz.U. z 2016r. poz. 2255

[15] World report on disability: summary(2011) Nr I/2013(6) World Health Organization, WHO

[16] Zapotoczna M. (2014), Taksonomicznaanalizaprzestrzennegozróżnicowaniapotrzebmieszkaniowych w Polsce. J. Potocki, J. Ładysz (red) Gospodarka przestrzenna, Aktualne aspekty polityki społeczno-gospodarczej i przestrzennej. Prace Naukowe UE we Wrocławiu nr 367, 378-386 